\title{
Los poemas en prosa de César Vallejo. La transición de lo narrativo a lo poético
}

\author{
María Ema Llorente ${ }^{1}$
}

Resumen. En el presente artículo se defiende la idea de que la escritura del poema en prosa en César Vallejo no se realiza de una manera caótica o desestructurada, sino que, por el contrario, existe una cierta sistematización o regularidad en este proceso, que tiene que ver con la distribución estructural de los elementos narrativos y los poéticos, situados al inicio y al final de los poemas respectivamente. Según esta idea, se estudian algunas de las formas en las que lo poético se inserta en lo narrativo, provocando como resultado la ambigüedad característica de este tipo de composiciones.

Palabras clave: género literario; ritmo; abstracción; tiempo presente; metáfora.

\section{[en] Prose poems in Cesar Vallejo. The transition from narrative to poetic}

\begin{abstract}
This article focuses on the idea that the writing of the prose poem in Cesar Vallejo is not performed in a chaotic or amorphous way, but, on the contrary, there is a certain systematization or regularity in this process, which has to do with the structural distribution of the narrative and the poetic elements, located at the beginning and the end of the poems respectively. According to this idea, the article explores some of the ways in which these poetic elements are inserted in the narrative discourse, causing as a result the ambiguous nature of this type of compositions.
\end{abstract}

Keywords: literary genre; rhythm; abstraction; present tense; metaphor.

Sumario. 1. Ritmo repetitivo y paralelístico. 2. Temporalidad indeterminada, universal o mítica. 3. Metáforas, comparaciones e imágenes.

Cómo citar: Llorente, $\mathrm{M}^{\mathrm{a}}$. E. (2017) Los poemas en prosa de César Vallejo. La transición de lo narrativo a lo poético, en Anales de Literatura Hispanoamericana 46, 221-238.

El estudio del poema en prosa, como manifestación genérica relativamente reciente $^{2}$, innovadora e híbrida, plantea, por estas mismas razones, una serie de

1 Universidad Autónoma del Estado de Morelos (UAEM), México.

E-mail: emmall@uaem.mx

2 Muchos autores, entre los que se encuentra por ejemplo Pedro Aullón de Haro, sitúan la aparición del poema en prosa en el Romanticismo, manifestación que se verá consolidada después por el Modernismo, en su deseo de ennoblecer la prosa y acercarla al verso (1979: 109). Las razones aportadas para tal ubicación tienen que ver, por un lado, con el deseo romántico de unión de las distintas artes -literatura, música y pintura-, espíritu unificador al que también responde la combinación de prosa y verso, acorde con el principio de libertad de expresión y la propuesta de disolución de los géneros literarios de este movimiento. Por otro lado, y como señala Benigno León, este surgimiento se relaciona igualmente con la idea de que para el Romanticismo la poesía o lo poético no se limita a una forma específica, por lo que la prosa es vista como un vehículo válido 
problemas particulares que no suscitan los géneros literarios convencionales. Entre estos problemas se encuentran, por ejemplo, su consideración o no como género literario; sus diferencias con los otros géneros, y especialmente con el poema escrito en verso libre o versículo mayor; la determinación de si su especificidad proviene únicamente de su forma o también de su naturaleza; y los problemas relativos a su nombre, su extensión, su autonomía y su propósito ${ }^{3}$.

Todas estas cuestiones se suman, en el caso de los poemas en prosa de César Vallejo, a las dificultades textuales que plantea el corpus o conjunto de textos que pueden considerarse dentro de esta categoría, derivadas, en parte, de las circunstancias concretas de su escritura y su publicación ${ }^{4}$.

Una parte de los poemas en prosa de este autor se encuentra recopilada en el poemario titulado precisamente Poemas en prosa, obra que por ser una publicación póstuma y por no existir un manuscrito revisado y ordenado por el mismo poeta, ha dado lugar a todo tipo de especulaciones, polémicas y divergencias entre los críticos de su obra, entre las que se encuentran, por citar algunas, las discusiones sobre el título; las diferencias entre las distintas ediciones y sus variantes; el desacuerdo sobre las fechas de escritura; los cambios en el orden de aparición de los poemas en el poemario; su concepción o no como libro independiente; y el número total de poemas que integran el libro, entre otros aspectos ${ }^{5}$.

Además de los problemas textuales que suscita la obra mencionada, hay que tener en cuenta que la escritura del poema en prosa no se limita en Vallejo a este único poemario, sino que se prolonga antes y después de él, y se desarrolla paralela o simultáneamente a su escritura de poemas en verso ${ }^{6}$. Según esta idea, existirían antecedentes de la escritura del poema en prosa en Trilce, en poemas como los numerados LV, LXIV, LXX y LXXV, que ya se han señalado como germen de este tipo de escritura. De la misma forma, podría reconocerse la escritura del poema en prosa en obras posteriores como Poemas humanos, de la que el poema "En suma no poseo", se ha incluido igualmente dentro de esta misma categoría (Borgeson 1986: 142).

para la expresión poética. A esto se suma el hecho de que las traducciones de poemas en verso a otros idiomas supusieron, en algunos casos, su prosificación en el idioma de destino, con lo que quedaba demostrado que el metro y la rima no constituían un elemento esencial para la expresión poética (2005: 9-14).

3 En la revisión y enumeración de estas cuestiones sigo, básicamente, los estudios de Guillermo Díaz Plaja (1956), Suzanne Bernard (1959) y Benigno León (2005).

4 La publicación póstuma de esta obra, que fue editada por su esposa Georgette Vallejo en París en 1939, dejó muchas dudas en relación con el objetivo o el propósito original de este libro. Según Américo Ferrari, y tal como puede apreciarse en la correspondencia de Vallejo del año 1935, el autor tenía la intención de publicar un libro, tal vez dedicado por entero a la prosa poética, que sería mucho más amplio de lo que se ha conservado (1972: 273). Por su parte, Julio Vélez, responsable de la edición de los Poemas en prosa de la editorial Cátedra, señala que César Vallejo difícilmente hubiera publicado Poemas en prosa y Poemas humanos tal como hoy los conocemos (Vallejo 1988: 22).

5 En relación con las distintas ediciones de los Poemas en prosa de Vallejo y con otros problemas planteados por la publicación de esta obra véase Américo Ferrari (1972), cap. IV.

6 Este acercamiento a los poemas en prosa de César Vallejo pone de manifiesto, indirectamente, el problema de la continuidad o la ruptura en el conjunto de la producción literaria de este autor. La mayoría de críticos, sin embargo, se inclina más, en el caso de los poemas en prosa, por la idea de la continuidad. Por ejemplo Francisco Martínez defiende la idea de una continuidad sin rupturas definidas o cortes bruscos, según lo cual, el poemario Poemas en prosa sería un punto de enlace entre lo anterior y lo siguiente (1976: 166). En la misma línea se orientan las opiniones de Guillermo Alberto Arévalo, quien señala igualmente la cualidad de transición o enlace de los Poemas en prosa entre las obras anteriores y posteriores (1977: 108). 
Además de lo anterior, y dado que los poemas en prosa son una manifestación genérica de carácter híbrido, también se ha mencionado la relación de estos textos con los relatos de este autor. Por ejemplo, Guillermo Sucre ha calificado de poemas en prosas algunos de los textos que aparecen en Escalas melografiadas, de 1923 (1985: 126). Américo Ferrari, comentando los cuentos de esta misma obra, afirma igualmente que éstos "contienen fragmentos líricos que hacen pensar en los futuros poemas en prosa, aunque predomina la forma narrativa" (1972: 269 nota 1). Y, finalmente, también se han considerado como poemas en prosa algunos de los textos que aparecen en Contra el secreto profesional, obra miscelánea escrita aproximadamente entre 1923 y 1929:

... hay que destacar el hecho de que Contra el secreto no sea sólo un volumen de narraciones o relatos, al modo de los denominados Cuentos inéditos. Su característica es la de ser una obra abierta, un libro en proceso, de perfil miscelánico porque en él se han compilado anotaciones, citas, poemas en prosa, "fabulaciones” y “consorcios narrativos plurales" (González 2002: 29-30).

Sin negar la existencia de antecedentes y continuaciones de este tipo de escritura en César Vallejo, me centraré exclusivamente, para el análisis de este trabajo, en doce poemas, de los diecinueve que componen Poemas en prosa, que considero que pueden englobarse en esta categoría, y que, además de estar efectivamente escritos en prosa ${ }^{7}$, se ajustan a las características de brevedad, unidad e intencionalidad, indicadas para este género por especialistas como Suzanne Bernard (1959), Maurice Chapelan (1946) y Benigno León (2005) .

Creo que en todos estos poemas pueden encontrarse características comunes y mecanismos textuales y compositivos similares y recurrentes, lo que permite plantear la existencia de una cierta sistematicidad o una estructura del poema en prosa en este autor $y$ en esta obra, conseguida a través de una particular articulación entre lo narrativo y lo poético y de su disposición o presentación en el poema, lo que constituirá el objetivo principal de este trabajo.

La constatación de que existe una lógica interna en la escritura de este tipo de poemas contribuiría, por un lado, a desterrar la concepción negativa que en ocasiones se tiene de este tipo de composiciones, de las que se ha señalado su carácter anárquico, caótico y disperso, y por otro, serviría también para defender su particularidad como género literario, para lo que estos textos necesitarían,

\footnotetext{
Los títulos de estos 12 poemas son: "El buen sentido", "La violencia de las horas", "Lánguidamente su licor", "El momento más grave de la vida", "Las ventanas se han estremecido...", "Voy a hablar de la esperanza", "Hallazgo de la vida", "Una mujer...", "No vive ya nadie...", "Existe un mutilado...", "Algo te identifica...", y "Cesa el anhelo...".

8 En relación con el criterio de la intencionalidad, Maurice Chapelan, en su "Introducción" a la Anthologie du poème en prose, precisa que sólo se pueden considerar poemas en prosa aquellos textos cuyos autores señalaron de alguna manera que querían hacer tal cosa (1946). También para Susanne Bernard el poema en prosa supone una voluntad consciente de organización de la materia en poema (1959: 14). El problema de este criterio es que no siempre existen declaraciones del autor sobre su propia obra. Benigno León intenta dar solución a esta cuestión, aludiendo a lo que denomina una "intencionalidad implícita", que puede apreciarse, según el autor, en dos tipos de manifestaciones: 1) la presencia de textos en prosa insertos en poemarios en verso de un autor; y 2) la existencia de textos en prosa breves y de tono lírico en autores cuya producción sea íntegramente poética (2005: 20). Según esto, creo que los poemas en prosa de César Vallejo señalados podrían calificarse plenamente como tales.
} 
precisamente, según los especialistas, contar con ciertas leyes o reglas constitutivas de carácter general. ${ }^{9}$

Una de estas leyes o recurrencias constitutivas es, precisamente, la propia ambigüedad o ambivalencia interna de este tipo de manifestaciones, que combina la escritura prosificada con elementos propios del género lírico. Autores como Michael Riffaterre, atendiendo a esta hibridez intrínseca, califica esta escritura como esencialmente contradictoria (1983: 150-157). También $\mathrm{M}^{\mathrm{a}}$ Victoria Utrera Torremocha, coincidiendo con la idea expresada por el crítico francés, afirma que: "el poema en prosa, en general, se caracteriza por un modo de enunciación específica que estriba en el encuentro semántico y estilístico de aspectos contrapuestos" (1999: 17).

Esta particularidad genérica de la escritura del poema en prosa en general está presente también en los poemas de César Vallejo y es responsable, en mi opinión, de parte del efecto de extrañeza que estos textos provocan. La confluencia entre elementos narrativos y poéticos no ocurre, sin embargo, de una manera aleatoria o indiscriminada, sino que, por el contrario, obedece, desde mi punto de vista, a una lógica interna de composición. Según esta lógica, los elementos narrativos aparecen de manera más frecuente al principio y en el medio del poema, mientras que los elementos líricos o poéticos suelen situarse al final. Es decir, muchos de estos poemas se inician con un tipo de escritura propia del discurso narrativo -con una determinación o concreción espacio-temporal, y una apariencia de progresión o avance de la acción- que va siendo sustituida por elementos propios de un discurso lírico -como la ausencia de detalles espacio-temporales, el predomino de la abstracción, el uso de un presente general o universal y la presencia de metáforas irracionales-. Esta transición de un tipo de elementos discursivos a otros provoca un cambio o una dislocación en la lectura y en el lector, lo que rompe sus expectativas y le obliga a terminar de leer en muchos casos en clave lírica algo que había empezado a leer y a entender en clave narrativa ${ }^{10}$.

Esto puede verse, por ejemplo, en el poema "Hallazgo de la vida", que se inicia con una fórmula discursiva que semeja o imita un discurso oral en prosa:

9 En relación con estas ideas, Benigno León afirma lo siguiente: "El poema en prosa, además, y por su propio origen y naturaleza, tiende más a la dispersión formal que a su homogeneización, hecho que dificulta no sólo su recepción, sino también su delimitación como género literario" (2005: 10). Por su parte, Suzanne Bernard, en la misma línea de pensamiento, apunta que el poema en prosa posee un principio anárquico y destructor de las leyes de la poesía, pero señala también la necesidad de que estas leyes se sustituyan por otras, para que este tipo de escritura no caiga en lo inorgánico o lo informe, y pueda ser considerado como un género literario (1959: 13).

$10 \mathrm{M}^{\mathrm{a}}$ Victoria Utrera Torremocha, comentando la función de guía u orientación para la lectura que desempeñan los géneros literarios en general y también, de manera específica, el poema en prosa, afirma lo siguiente: "Es evidente que para los mismos autores el género posee una serie de valores relacionados con un nuevo concepto de la poesía, que se debe sin duda al hecho de estar escrito en prosa y no en verso. La disposición tipográfica se convierte en señal que predispone a una lectura determinada, unida a una serie de valores culturalmente asociados al discurso prosístico... Así, el género del poema en prosa, visto en el marco de la semiótica literaria y a la luz del campo de la pragmática sirve, como todo género, de norma para guiar al lector... Al tiempo que se vincula al ámbito de la poesía por ciertas características -atemporalidad, autonomía y coherencia significativa en un nivel simbólico, etc.-, asume, gracias al empleo de la prosa y a los rasgos que se le atribuyen tradicionalmente, los valores de naturalidad y autenticidad. Pero en la práctica, el poema en prosa, como otros géneros prosísticos, está sujeto al artificio literario y posee sus propias reglas que, desde su cualidad antitética, impone al lector, creándole una serie de expectativas y determinando una lectura diferente que exige... la conjunción de lo poético y lo prosaico y que supone un concepto más amplio de la poesía" (1999: 18). 
"iSeñores! Hoy es la primera vez que me doy cuenta de la presencia de la vida", y que termina, sin embargo, con una afirmación metafórica o poética: “¡Dejadme! La vida me ha dado ahora en toda mi muerte" $(100-101)^{11}$.

De la misma manera, un poema como "Lánguidamente su licor" se abre con una fórmula propia del relato, que hace esperar el desarrollo posterior de una anécdota: "Tendríamos ya una edad misericordiosa, cuando mi padre ordenó nuestro ingreso en la escuela", y que sin embargo concluye, como se verá más adelante, con la metaforización del extraño episodio de la gallina clueca que "tuvo el verbo" (9294).

Según esto, los inicios narrativos de estos textos, motivados o condicionados tal vez por el cauce de la escritura en prosa y por las reminiscencias de una tradición de textos literarios breves configurados con este tipo de escritura como los cuentos, las fábulas y las parábolas ${ }^{12}$, con las que se ha relacionado a los poemas en prosa de manera explícita, se van transformando o van incorporando elementos poéticos, en una transición que, a mi modo de ver, no podría producirse en sentido inverso.

La evolución interna o la transición de lo narrativo a lo poético apuntada para estos poemas se traduce textualmente, en muchos casos, como ya se mencionó, en un paso de lo concreto a lo abstracto, de lo determinado a lo indeterminado, o de lo particular a lo general. Los detalles puntuales y los elementos anecdóticos iniciales se suspenden para dar paso a reflexiones o afirmaciones de carácter general, no circunstanciales, e incluso fantásticos, inverosímiles o imposibles desde el punto de vista lógico y sólo explicables o aceptables desde la irrealidad de lo metafórico. Con esto se pone de manifiesto que el propósito de este tipo de composiciones no es la transmisión de una historia, ni el avance o la evolución de la diégesis, pues las historias o las anécdotas comenzadas no tienen una resolución o una conclusión lógica ni narrativa, sino que más bien persiguen un determinado efecto expresivo, impresionante o estético, efecto que se privilegia por encima de la racionalidad del discurso.

Desde esta concepción pueden entenderse afirmaciones como la que realiza el hablante de "El buen sentido", que indica que su madre le ajusta el cuello del abrigo "no porque empieza a nevar, sino para que empiece a nevar" (89), que supone una clara violación de la lógica o de la dirección causa-efecto, violaciones que son bastante frecuentes, por otro lado, en los textos de los Poemas en prosa ${ }^{13}$.

Para intentar dar cuenta de la forma en que lo narrativo y lo poético se integran o se articulan en estos textos, según la progresión o transición interior señalada, me centraré en tres mecanismos o aspectos textuales concretos en los que se manifiesta esta evolución, como son 1) la intensificación progresiva del ritmo del poema que se produce mediante el uso de las repeticiones y los paralelismos; 2) el predominio de una temporalidad indeterminada, universal, o mítica; y 3) la presencia de imágenes, comparaciones y metáforas que, situadas por lo general hacia la mitad o

11 Para las citas de los poemas de César Vallejo sigo la edición de Poemas en prosa de Cátedra, realizada por Julio Vélez en 1988, de la que indicaré en adelante únicamente los números de página correspondientes.

12 La intertextualidad como característica inherente a los poemas en prosa y su relación con formas discursivas previas como los cuentos, las fábulas, los diarios e incluso las cartas ha sido ya señalada por autores como Francisco Martínez (1976) y Elisa Dávila (1983).

13 Esta inversión de las relaciones causales es uno de los mecanismos que menciona Emily Schneider como uno de los responsables del proceso general de inversión y subversión que opera, según la autora, en los Poemas en prosa de Vallejo (1990: 181-209). 
final del texto, alejan el texto de lo narrativo inicial y lo acercan o lo conducen hacia lo lírico o lo poético.

\section{Ritmo repetitivo y paralelístico}

Tanto el ritmo como los diferentes efectos que se consiguen a través de su empleo son los primeros mecanismos que podrían señalarse como responsables del abandono de lo lineal y lo narrativo y del acercamiento a lo poético que se produce en estos textos.

Aunque el ritmo no es un elemento privativo de la poesía, pues también la escritura en prosa puede y suele estar dotada de ritmo, sí puede considerarse algo más propio de ella, a lo que la escritura narrativa en prosa antepone el orden de la exposición lógica o racional de su contenido. Como señala Domínguez Caparrós: "Lo fundamental para comprender lo que distingue la prosa del verso es observar que la división de las unidades rítmicas de la prosa (periodos y miembros de periodos) se funda en razones lógico-sintácticas, mientras que en el verso el esquema rítmico impone su división" (2000: 27).

Octavio Paz, por su parte, reflexiona sobre las particularidades del ritmo y las diferencias que éste presenta en la prosa y en el verso o el poema de la siguiente manera:

¿Cómo distinguir, entonces, prosa y poema? De este modo: el ritmo se da espontáneamente en toda forma verbal, pero sólo en el poema se manifiesta plenamente. Sin ritmo, no hay poema; sólo con él, no hay prosa. El ritmo es condición del poema, en tanto que es inesencial para la prosa. Por la violencia de la razón las palabras se desprenden del ritmo... Mas ese desarraigo nunca es total, porque entonces el lenguaje se extinguiría (1972: 68).

Como el mismo autor señala más adelante, este ritmo no se consigue sólo mediante la medida de los versos, tal como ocurre en los poemas isométricos, sino que también se hace posible gracias al uso de otras unidades rítmicas (1972: 72). Entre estas otras posibilidades se encuentra la repetición de palabras y estructuras sintácticas, como en el caso del paralelismo.

Este tipo de repetición estructural puede verse, por ejemplo, en poemas como "La violencia de las horas", en el que se utiliza la repetición de la palabra "murió" para enumerar las distintas personas que conocía el hablante y que ya no existen, en lo que puede considerarse una formulación moderna del tópico del Ubi sunt?:

Todos han muerto.

Murió doña Antonia, la ronca, que hacía pan barato en el burgo.

Murió el cura Santiago, a quien placía le saludasen los jóvenes y las mozas, respondiéndoles a todos, indistintamente: "Buenos días, José! Buenos días, María!". 
Murió aquella joven rubia, Carlota, dejando un hijito de meses, que luego también murió a los ocho días de la madre.

Murió mi tía Albina, que solía cantar tiempos y modos de heredad, en tanto cosía en los corredores, para Isidoro, la criada de oficio, la honrosísima mujer (90-91).

El mismo tipo de repetición aparece también en "El momento más grave de la vida", título cuya frase se repite a lo largo de todo el poema con diferentes desarrollos:

Un hombre dijo:

- El momento más grave de mi vida estuvo en la batalla del Marne, cuando fui herido en el pecho.

Otro hombre dijo:

-El momento más grave de mi vida, ocurrió en un maremoto de Yokohama, del cual salvé milagrosamente, refugiado bajo el alero de una tienda de lacas.

Y otro hombre dijo:

-El momento más grave de mi vida ha estado en mi mayor soledad (94).

Estas repeticiones cíclicas o recurrentes van marcando un ritmo progresivo y ascendente con el que el poema, en lugar de desarrollar de manera lineal y narrativa la anécdota o la historia apuntada al inicio, se va alejando de ella para llegar a afirmaciones más personales o individuales, dotadas de una mayor carga emocional y expresiva.

En el primero de los poemas mencionados, "La violencia de las horas", la enumeración acumulativa de las personas muertas, realizada al principio de una manera coherente y lógica, va dejando paso progresivamente a afirmaciones más abstractas, teñidas de un lenguaje más metafórico, que confiere al texto una cierta irracionalidad:

Murió Lucas, mi cuñado en la paz de las cinturas, de quien me acuerdo cuando llueve y no hay nadie en mi experiencia.

Murió en mi revólver mi madre, en mi puño mi hermana y mi hermano en mi víscera sangrienta, los tres ligados por un género triste de tristeza, en el mes de agosto de años sucesivos.

Este poema concluye, finalmente, con una afirmación ya completamente poética: "Murió mi eternidad y estoy velándola" (92).

De la misma forma, la acumulación que aparece en el segundo poema mencionado, "El momento más grave de la vida", avanza también de una manera 
progresiva, para terminar con una afirmación igualmente lírica: "El momento más grave de mi vida no ha llegado todavía" (95).

En estos ejemplos puede verse cómo las repeticiones que aparecen en estos poemas y el efecto rítmico que producen alejan, de alguna manera, el texto de lo narrativo y lo acercan más a lo poético o lo lírico. Y es que en este volver a decir que realiza la repetición idéntica de palabras y expresiones, podría verse una cierta forma de verso o de versus, contraria, desde el punto de vista externo, a la disposición formal de la prosa o prorsus, que se proyecta hacia adelante, según las etimologías correspondientes a estas dos denominaciones (Utrera, 1999: 13).

Mediante estas repeticiones y mediante el ritmo creado por ellas, es como si la prosa dejara de serlo y se negara a sí misma, acercándose a la escritura en verso, dominada o regida por otros intereses. Esto es lo que ocurre, según Octavio Paz, en algunas composiciones literarias que, a pesar de estar escritas en prosa, pueden considerarse poéticas, pues en ellas: "la prosa se niega a sí misma; las frases no se suceden obedeciendo al orden conceptual o al del relato, sino presididas por las leyes de la imagen y el ritmo" (1972: 72).

Además de esto, puede decirse que el ritmo generado en estos poemas va creando o sugiriendo también, con su tempo, una significación propia, que, en el caso de las repeticiones estructurales o paralelísticas, se acerca a lo mágico o lo sagrado, por el efecto envolvente e hipnótico que poseen. Esto permite relacionar estos poemas en prosa con ciertas oraciones y letanías, tal como han hecho ya autores como Américo Ferrari:

... ciertos poemas (en prosa) se presentan bajo la forma de letanías, en las que la repetición monótona de una misma expresión desde el principio hasta el final imprime al poema un ritmo acezante, lento y grave, que aísla y filtra ... la obsesión esencial que domina al poeta" (1972: 282).

Unida a la función de subrayar o destacar, a modo de estribillo, esa idea u "obsesión" central del poema, el ritmo provocado por este tipo de repeticiones tiene también un cierto efecto desrealizador, que, en el caso de los poemas en prosa de este autor, coincide con la transición de lo narrativo a lo poético, o de lo racional a lo irracional.

Mark Smith, comentando el fenómeno o el recurso de la repetición en la obra de César Vallejo, hace hincapié precisamente en ese "hechizo de la repetición", según el cual "la misma estructura sintáctica se repite en cada estrofa para crear el efecto de una oración o invocación mágica” (1983: 82-83).

Este efecto de oración o invocación se hace más evidente en otros poemas, en los que a la repetición paralelística se suma el calco y la inversión de fórmulas y de discursos religiosos previos, como los de los Salmos bíblicos. Se trata del tipo de repetición que aparece, por ejemplo, en el poema "Existe un mutilado...", que por ser un mutilado "del rostro": "No tiene ojos y ve y llora. No tiene narices y huele y respira. No tiene oídos y escucha. No tiene boca y habla y sonríe. No tiene frente y piensa y se sume en sí mismo". El poema finaliza de la siguiente forma: "Jesús conocía al mutilado de la función, que tenía ojos y no veía y tenía orejas y no oía. 
Yo conozco al mutilado del órgano, que ve sin ojos y oye sin orejas" (105-106), en una clara inversión de las palabras del Salmo 115 del Antiguo Testamento ${ }^{14}$.

Un tipo de alusión bíblica similar aparece en el poema "Las ventanas se han estremecido...", en el que se describe la situación de unos enfermos en un hospital que está siendo sacudido por un huracán. En este poema, el hablante es un enfermo más, posible correlato del propio Vallejo, que parece transcribir lo que ve y lo que le rodea y que, enfocándose en la figura de una mujer que acompaña a un enfermo, reflexiona con un párrafo de claras reminiscencias bíblicas:

... le besa y no puede sanarle con el beso, le mira y no puede sanarle con los ojos, le habla y no puede sanarle con el verbo. ¿Es su madre? ¿Y cómo, pues, no puede sanarle? ¿Es su amada? ¿Y cómo, pues, no puede sanarle? ¿Es su hermana? ¿Y cómo, pues, no puede sanarle? ¿Es simplemente una mujer? ¿Y cómo, pues, no puede sanarle? Porque esta mujer le ha besado, le ha mirado, le ha hablado y hasta le ha cubierto mejor el cuello al enfermo y ¡cosa verdaderamente asombrosa! no le ha sanado (97).

El eco de los Salmos bíblicos en la escritura del poema en prosa no es, sin embargo, algo exclusivo de César Vallejo, sino que parece ser frecuente en estos textos, que, como han señalado algunos críticos, tienen como origen o "raíces" estas composiciones. (Elisa Dávila 1983: 42).

De esta forma, además de servir como antecedente textual o formal en el que se unen lo lírico con lo narrativo, los Salmos y las letanías contribuyen a crear el efecto de extrañamiento señalado, al unir a lo poético del poema lo profético, lo oracular o lo mítico de los contenidos bíblicos.

Este uso literal y explícito de sentencias breves, expresiones o frases cortas de la Sagradas Escrituras, los Salmos y las letanías, también llamadas logion o logia en la terminología de la exégesis bíblica, no debe interpretarse, sin embargo, en relación con una intención religiosa o doctrinal de los textos, sino que tiene que entenderse más bien en su aspecto funcional, utilitario o compositivo (Martínez, 1988: 647-706). Este tipo de expresiones forma parte de un acervo lingüístico al que el poeta, educado en un contexto religioso, recurre para su creación literaria, acervo que contribuye a la depuración de la expresión y del objeto poético construido a través de ella:

...los motivos que objetivamente se detectan en los textos no son ideológicamente religiosos, sino paladinamente lingüísticos y poéticos, o, lo que es lo mismo, que no tienen por qué ser considerados necesariamente como indicadores de vivencias religiosas del propio autor, sino como estrategias estilístico-expresivas, empleadas funcionalmente por él, con el fin de lograr un

14 Como señala Francisco Martínez, este fragmento, aunque no asociado a Jesucristo ni al Nuevo Testamento, hace referencia al Salmo 115 (113 B) del Antiguo Testamento: "Los ídolos de ellos, plata y oro,/ obra de mano de hombre./ Tienen boca y no hablan,/ tienen ojos y no ven,/ tienen oídos y no oyen,/ nariz tienen y no huelen./ Tienen manos y no palpan, / tienen pies y no caminan,/ ni un solo susurro en su garganta". En palabras del mismo autor, aunque la referencia no es estrictamente del NT, sí existe, al parecer, una referencia parecida en el Evangelio a Isaías, 6, 9 ss, en la que se dice: "por mucho que miren no vean, por mucho que oigan no entiendan" (Mc, 4, 12) (1988: 653, nota 40). 
acendramiento, lo más apurado posible, del resultado final del objeto poético (Martínez 1988: 713).

A pesar de funcionar como estrategias estilístico-expresivas, esta serie de alusiones bíblicas y religiosas conforma también, más allá de su contenido religioso, un conjunto verbalizado de experiencias del pasado, que adquiere en este caso, por esta misma razón, las connotaciones positivas del recuerdo de la infancia, la madre, el hogar y la patria. Como señala el mismo crítico:

Para Vallejo, en el principio existió la madre, la familia. En un ambiente medularmente empapado de esencias religiosas, entendidas en el más estricto y tradicional sentido de los términos, [...] la oración hogareña de la tarde, el aprendizaje de la doctrina cristiana, la asistencia indefectible y ejemplar a las ceremonias litúrgicas, a los sermones y actos piadosos, y la escucha primero y lectura después de libros sagrados, fueron elementos conformadores de una realidad sacralizada en la que las formulaciones lingüísticas nacían pletóricamente preñadas de vocablos bíblicos, evangélicos, litúrgicos, catequéticos, piadosos y cristianos (1988: 707).

La utilización de estas fórmulas puede verse como una forma de evocación, como un intento de recuperación de esa realidad sacralizada y esas vivencias del pasado que buscan actualizarse desde el presente de un espacio distinto y distanciado de su tierra natal, como es la ciudad de París. Por este motivo, el viaje a París resultará una circunstancia vital determinante para la escritura de los Poemas en prosa, que incidirá, entre otras cosas, en la construcción de una temporalidad indeterminada o distorsionada, como se analizará a continuación.

\section{Temporalidad indeterminada, universal o mítica}

Además del ritmo y la repetición, otra de las características del discurso poético que aparece en los poemas en prosa en combinación con los aspectos narrativos es la presencia de una temporalidad personal y subjetiva, no determinada por las exigencias de la sucesión narrativa y la consecutio temporum, sino más en consonancia con las formas de expresión de una temporalidad poética. Como señalan algunos autores, el uso de la temporalidad en poesía no está tan limitado o restringido como en la prosa, sino que resulta algo más libre, al no estar al servicio de la lógica del discurso, razón por la que en ella pueden aparecer fenómenos de dislocación temporal como las superposiciones y las yuxtaposiciones (Bousoño 1985, I: 389-411).

En la producción poética de César Vallejo en general, se ha llamado ya la atención sobre estos usos alterados de la temporalidad, que resultan, por lo demás, bastante audaces, y que no se limitan exclusivamente a los poemas en prosa estudiados aquí. En otras obras de este autor puede apreciarse el uso personal que se hace de los tiempos y modos verbales, que revela una gran vacilación e indeterminación (Martínez 1976). 
Se trata, por ejemplo, de los conocidos versos: "César Vallejo ha muerto: le pegaban/ todos sin que él les haga nada", del poema "Piedra negra sobre piedra blanca", de Poemas humanos; de "el niño pega/ sin que le diga nadie que pegara", del Poema II, de España, aparta de mí este cáliz; y de "el traje que vestí mañana", del poema VI de Trilce.

Giovanni Meo Zilio interpreta estas violaciones de la siguiente manera:

... se dan dos inversiones modales en la consecutio temporum, que constituyen formalmente no sólo una violación de la "forma", sino una auténtica fractura del "sistema" lingüístico, que señala, a su vez, el desconcertante sentimiento temporal del poeta. ... La razón espiritual de esta turbación sintáctica se debe buscar en el hecho de que Vallejo, en el primer caso, ha querido proyectar en su presente histórico, su actual participación anímica en aquellos "golpes" que se remontan a la infancia; en el segundo caso ha querido proyectarla retrocediendo en el pasado para establecer una continuidad afectiva (vivida) con su misma infancia (2002: 84).

En todos estos casos, la intención parece ser, como señala Meo Zilio, actualizar el pasado y hacerlo presente en el momento de la enunciación, señalando, de esta forma, la continuidad o la pervivencia de las experiencias y las sensaciones.

El uso de estas formas verbales desgastadas en la escritura de Vallejo no responde, pues, a ninguna exigencia gramatical, ni está al servicio de una información temporal real, sino que, pretende, por el contrario, anular los valores temporales y desdibujar las fronteras entre los distintos tiempos, para situar el poema en un tiempo indeterminado y permanente. Como señala también Martínez, el uso intencional de estos aspectos y modos verbales contribuye a: "crear (o al menos resucitar) un matiz modal nuevo y una nueva perspectiva temporal en la que se dé la indistinción pasado-presente-futuro", para lograr con esto: "una de las características de su temporalidad a la que se podría calificar de mítica" (1976: 159-160).

En el caso de los poemas en prosa, esta temporalidad indiferenciada se manifiesta de forma especial en el uso de un tiempo presente que cumple, a manera del presente histórico narrativo, y entre otras funciones que se analizarán más adelante, esta función de acercamiento de lo acontecido en el pasado al momento de la expresión poética.

En relación con esta necesidad de actualización del pasado hay que tener en cuenta las circunstancias personales del autor en el momento de la escritura de estos textos, realizada, como ya se dijo, lejos de Perú, en un París que ofrece un panorama totalmente diferente:

Poemas en prosa es una obra escrita en un momento importante de la trayectoria existencial de Vallejo. De ahí que su actitud psicológica personal ante la realidad sea muy distinta de la actitud que le embargaba en la composición de Los heraldos negros o de Trilce. Hay un hecho capital. Vallejo deja el Perú y viaja a Europa. Este hecho debe ser puesto en relación directísima con el cambio de visión del mundo que ya detectamos en Trilce. Salir del Perú es el abandono del 
"provincianismo" cultural e ideológico y la inmersión en un ambiente totalmente nuevo y distinto (Martínez 1976: 166-167).

Esta inmersión en un ambiente nuevo y lleno de dificultades, así como la distancia geográfica y las pérdidas vitales que ya ha padecido el autor en estos momentos de su vida, potencian aún más, en mi opinión, la tendencia de la escritura de Vallejo hacia el pasado y el recuerdo.

Algunos críticos ya han señalado cómo precisamente el recuerdo del tiempo y del espacio pasado y positivo constituye uno de los ejes básicos y constructivos de toda la poética vallejiana, que se revela como marcada por una constante dinámica del retorno (Coddou 1975: 105). Saúl Yurkievich menciona también la función de refugio que adquieren estas vivencias del pasado, a las que el poeta acude en tiempos de dificultad:

En medio del desmoronamiento, las ínsulas dichosas, los pocos refugios cálidos son ciertos paraderos del pasado: recuerdos de la infancia, una mujer amada. Instantes de luz que se han fijado en la memoria y a los que el poeta, en su desasosiego, vuelve para buscar la calma. Entre las evocaciones felices, la más intensa, la de la madre, figura añorada (1971: 31).

Según esta idea, y tal como apunta asimismo Mariano Ibérico, el pasado es para este autor el tiempo de la infancia, pero también el tiempo "maternal", un tiempoespacio "benigno y productivo", que se conformará como un lugar-refugio, un lugar alternativo y siempre actualizable y presente en el que ampararse en la vida adulta, que supone, a diferencia del "maternal", un tiempo de la "derrelicción", el abandono o el desamparo (1965: 47-63). Ése es, pues, el espacio y el tiempo positivo y mítico al que creo que remiten muchos de los poemas en prosa mediante el uso de una temporalidad abstracta, que se aleja de lo concreto y de lo contingente, de lo exigido por la lógica y la coherencia narrativa, para instaurar un tiempo continuo o eterno, que se expresa de una manera muchas veces ilógica, y hasta agramatical, que está más al servicio de la comunicación o la transmisión de un determinado mundo personal, que de la sucesión del discurso narrativo.

Un ejemplo de este uso del presente como actualización o perpetuación del pasado lo constituye el poema "El buen sentido", poema inicial del libro que, además, y como señalaba Yurkievich, tiene como tema central el recuerdo de la madre y la casa materna. El poema, que presenta un inicio semejante al de una carta, una entrada de diario o una conversación - "Hay, madre, un sitio en el mundo que se llama París"-, está escrito, en su mayoría, en tiempo presente, a pesar de tratarse de una rememoración, realizada, probablemente, en el barco que llevaba a Vallejo a París ${ }^{15}$, cuando la madre del autor ya había fallecido:

La mujer de mi padre está enamorada de mí, viniendo y avanzando de espaldas a mi nacimiento y de pecho a mi muerte. Que soy dos veces suyo: por el adiós y el por el regreso.

15 Esto es lo que afirma de este poema Georgette Vallejo en las Obras Completas de César Vallejo, publicadas en Barcelona por la editorial Laia en 1977, tal como recoge Julio Vélez en su edición de los Poemas en prosa (Vallejo 1988: 89). 
Mi madre está confesa de mí, nombrada de mí. ¿Cómo no da otro tanto a mis otros hermanos? A Víctor, por ejemplo, el mayor, que es tan viejo ya, que las gentes le dicen: ¡Parece hermano menor de su madre!

Mi madre acuerda carta de principio colorante a mis relatos de regreso. Ante mi vida de regreso, recordando que viajé durante dos corazones por su vientre...

Y desfila por el color amarillo a llorar, porque me halla envejecido, en la hoja de espada, en la desembocadura de mi rostro (89-90).

La utilización del tiempo presente en estos poemas cumple, además, una segunda función expresiva, que puede asociarse o relacionarse con el carácter general o universal de la escritura poética. Contrariamente a lo que algunos críticos han señalado sobre el uso del tiempo presente en Vallejo, no creo que en estos poemas en prosa este uso responda a una intención de determinación ${ }^{16}$. Se trata más bien, en mi opinión, de un tiempo presente al servicio de la construcción de esa temporalidad mítica, general y abstracta, ajena, en la mayoría de los casos, a una función temporal y referencial concreta.

Con este uso del tiempo presente la escritura en prosa se acerca más a la poesía, caracterizada, precisamente, en opinión de algunos críticos, por desarrollarse en un presente intemporal y reactualizable, que puede considerarse mítico o arquetípico. Como señala Octavio Paz en este sentido, el tiempo del poema es: "un tiempo que es siempre presente, un presente potencial y que no puede realmente realizarse sino haciéndose presente de una manera concreta en un ahora y un aquí determinados. El poema es tiempo arquetípico" (1972: 188).

Este tipo de temporalidad indeterminada y al mismo tiempo arquetípica resulta ser un rasgo recurrente y repetitivo en Poemas en prosa. Aparece, por ejemplo, en ese "Hoy sufro solamente" que se repite como un estribillo en "Voy a hablar de la esperanza", y que se coloca también al final, como broche o cierre del poema (100). A pesar de su aparente concreción temporal en ese "hoy" y en el uso del tiempo presente, esta temporalidad no remite a ningún momento puntual ni concreto, sino que, por el contrario, convierte la afirmación en una frase de carácter general y universal, extensible a cualquier lector y a cualquier hombre, más allá del hablante particular del poema.

Algo semejante en relación con la temporalidad ocurre en "Las ventanas se han estremecido...". El uso del tiempo presente en este poema está, por un lado, al servicio de la actualización de un suceso puntual, ocurrido, supuestamente, con anterioridad a la escritura del poema, como es la ruptura de los vidrios de las ventanas provocada por un huracán. En lugar de relatarse este suceso concreto en

16 En relación con este tema afirma Américo Ferrari: “es preciso señalar además la insistencia con la que acuden en estos poemas los adverbios de tiempo: Ahora... hoy, que subsumen la obsesión dominante en cada poema en la experiencia concreta del tiempo. La presencia cada vez más frecuente de estos adverbios, así como de los demostrativos, este, ese, aquel, o de los pronombres personales, es una de las grandes constantes de la obra de Vallejo: visible ya en Los heraldos negros, se acentúa fuertemente en Poemas humanos. Resulta evidente que esta constante responde a la preocupación ansiosa del poeta por la determinación, a su angustia ante la frontera y el límite, las fechas, la individuación, el aquí y el ahora, en suma, frente a todo aquello que rompe la unidad del ser" (1972: 284). 
pasado, se elige el tiempo presente de nuevo como un presente histórico, que concede una mayor intensidad y cercanía a un suceso traumático o impresionante. Por otro lado, además de esta función, el presente que domina el resto del poema contribuye a la creación de una escena o una estampa, que combina la descripción de los enfermos, del hospital y de la labor de los médicos, con reflexiones personales del hablante poético, creando un efecto de ralentización o de tiempo detenido. Este tiempo presente se combina, hacia final del texto, con la repetición tanto literal como estructural, y con la metaforización de ese hospital que es ahora "la casa del dolor", lo que provoca que el poema se aleje nuevamente de las circunstancias concretas y personales y se convierta en algo universal o generalizable:

En la casa del dolor, la queja asalta síncopes de gran compositor, golletes de carácter que nos hacen cosquillas de verdad, atroces, arduas, $\mathrm{y}$, cumpliendo lo prometido, nos hielan de espantosa incertidumbre.

En la casa del dolor, la queja arranca frontera excesiva. No se reconoce en esta queja de dolor, a la propia queja de la dicha en éxtasis, cuando el amor y la carne se eximen de azor y cuando, al regresar, hay discordia bastante para el diálogo (98).

Finalmente, el poema termina con una repetición insistente y circular, cuya fragmentación o segmentación se encuentra muy cercana ya a la de un poema tradicional:

¡No es grato morir, señor, si en la vida nada se deja y si en la muerte nada es posible, sino sobre lo que se deja en la vida! ¡No es grato morir, señor, si en la vida nada se deja y si en la muerte nada es posible, sino sobre lo que se deja en la vida! ¡No es grato morir, señor, si en la vida nada se deja y si en la muerte nada es posible, sino sobre lo que pudo dejarse en la vida! (99).

\section{Metáforas, comparaciones e imágenes}

La tendencia a la indeterminación y la abstracción señalada para estos poemas en el apartado anterior se refuerza o se intensifica mediante el último de los procedimientos señalados, que es el uso de metáforas, comparaciones e imágenes. Estos procedimientos, que sin ser exclusivos del discurso poético podrían verse como el germen o el núcleo de lo lírico o lo poético por excelencia, aportan a estos textos un elevado grado de irracionalidad y fantasticidad, y son el recurso que mejor y de manera más radical evidencia el salto o la evolución de niveles que tiene lugar en el interior estos poemas.

En algunos de los ejemplos anteriores se vio ya cómo la aparición de metáforas, comparaciones e imágenes suele ir asociada a un proceso de desrealización o alejamiento de lo anecdótico y lo concreto, tal como ocurría al final de "La violencia de las horas" y "El momento más grave de la vida". 
De la misma forma, el poema "Voy a hablar de la esperanza", centrado sobre el tema del dolor y el sufrimiento del hablante, se inicia con diferentes aproximaciones e intentos de explicación de este dolor y de su causa, intentos que fracasan en su propósito. Finalmente, tras renunciar a estas explicaciones o negarlas de nuevo mediante repeticiones estructurales o paralelismos -"no sufro este dolor como César Vallejo", "no me duelo ahora como artista", "no sufro este dolor como católico, como mahometano ni como ateo"-, se recurre a una explicación metafórica: "Mi dolor es del viento del norte y del viento del sur". Esta afirmación, que podría parecer irracional o gratuita desde el punto de vista lógico, se puntualiza con una comparación: "como esos huevos neutros que algunas aves raras ponen en el viento" (99), con lo que se le otorga al dolor una especie de primera causa bíblica, que aleja la explicación del origen de ese dolor de los elementos concretos con los que se había iniciado el poema (Schneider, 1990: 190191). Es decir, donde no llega la lógica o la razón narrativa, interviene una lógica distinta, que es la lógica de la metáfora y la comparación subjetiva, más al servicio de la comunicación de realidades interiores y particulares.

Además de esta afirmación, en los Poemas en prosa hay otras imágenes que resultan irracionales, fantásticas o imposibles y que contribuyen a la creación de esa ambientación ambigua e indeterminada. Por ejemplo, el poema "Lánguidamente su licor", que tiene una clara estructura narrativa, se inicia con la descripción de una comida familiar, que cambia de rumbo o de dirección con la aparición de un personaje inesperado que comunica a los comensales una noticia presumiblemente fatal. Después de recibir esta noticia, e impelidos por las indicaciones del padre, todos deben continuar con la comida y con sus vidas como si nada hubiera pasado. Sin embargo, del carácter narrativo y secuencial con el que se había iniciado el poema, se pasa a lo poético o lo lírico, en la descripción de los efectos que esa noticia nefasta tienen en el interior del hablante poético, que describe su estado de emoción y dolor, cuya libre expresión se ve frustrada por las indicaciones paternas, mediante el recurso de la aparición de una gallina clueca en su garganta, metáfora, tal vez, del llanto reprimido:

Más, luego, de improviso, salió de un albañal de aguas movedizas y de aquel mismo patio de la visita mala, una gallina, no ajena ni ponedora, sino brutal y negra. Cloqueaba en mi garganta. Fue una gallina vieja, maternalmente viuda de unos pollos que no llegaron a incubarse. [...] La clueca después tuvo el verbo (93-94)

Con la aparición de esta metáfora, que resulta incoherente o incompatible con la evolución de la historia inicial, el poema da un giro de lo literal o real de la narración a lo no literal o imposible, que aparece, en este caso, no para desarrollar el desenlace narrativo del episodio, sino para introducir la vivencia emocional del mismo por parte del hablante. Esta idea se ve reforzada por la afirmación final del pasaje "La clueca después tuvo el verbo", que podría interpretarse, en este sentido, como la conversión de la emoción en palabra poética y en escritura.

Igualmente, en "La violencia de las horas" se puede encontrar también una imagen fantástica o irreal. Uno de los muertos de los que se habla en este poema es 
"el músico Méndez, alto y muy borracho", cuya música tenía, al parecer, el poder de dormir a las gallinas antes de tiempo: "solfeaba en su clarinete tocatas melancólicas, a cuyo articulado se dormían las gallinas de mi barrio mucho antes de que el sol se fuese" (91-92).

Por último, también podría incluirse en este tipo de imágenes la descripción del personaje que aparece en el poema "Existe un mutilado..." mencionado arriba, en el que se habla de un hombre sin rostro que, en lugar de haber sido mutilado en la guerra, lo fue en la paz, y no como resultado del odio, sino del amor. El poema presenta rasgos de narratividad en la forma en que se introduce a este personaje y se da cuenta de su existencia, así como en los detalles relativos al lugar y el momento en el que perdió supuestamente su rostro. A lo largo de esta estructura u organización narrativa se van insertando numerosas frases paradójicas y metafóricas, que añaden irracionalidad a este personaje, cuyo rostro inexistente se describe como "Rostro muerto sobre el tronco vivo. Rostro yerto y pegado con clavos a la cabeza viva. (...) el dorso del cráneo, el cráneo del cráneo" (104), y que "nació a la sombra de un árbol de espaldas", por lo que su existencia "transcurre a lo largo de un camino de espaldas" (105). Con la inserción de estos detalles y estas afirmaciones, el poema se aleja nuevamente del desarrollo lógico y lineal de la acción o de la historia para integrarse en un discurso poético que debe interpretarse en clave no literal o metafórica. Esta interpretación es la que permite identificar a este personaje "mutilado del abrazo" con el hablante mismo y contemplar lo dicho en el poema como una manera indirecta de expresar o manifestar, tal vez, otras pérdidas y desencantos vitales reales y concretos.

De todo lo anterior puede concluirse que los poemas en prosa de César Vallejo que aparecen en el poemario del mismo nombre no presentan una estructura casual, desordenada o irregular, sino que se ajustan a un principio compositivo propio o particular recurrente, que tiende a situar los elementos narrativos al inicio y al medio de la composición, y los poéticos al final. Según esta disposición, a lo largo del texto se produce una progresión o una evolución de lo narrativo a lo poético, lo que equivale a decir, en este caso, que tiene lugar una transición de un discurso organizado según criterios lógico-sintácticos, a un discurso organizado en función de criterios rítmicos y expresivos, que puede dejar de lado la racionalidad del discurso en beneficio de una mayor y más intensa expresión de lo emocional, lo personal y lo subjetivo.

En conjunto, en estos poemas puede observarse el abandono progresivo de la concreción o la determinación espacial, temporal y temática, en favor de una mayor abstracción e indeterminación, que los convierte, como ocurre muchas veces en poesía, en expresión de vivencias, sensaciones e ideas generales o universales.

Esta transición entre los elementos narrativos y los poéticos que componen el poema en prosa no podría producirse, en mi opinión, en la dirección contraria, pues la misma extensión de estos textos obliga, en cierta manera, lo mismo que ocurre en los poemas escritos en verso, a que exista una tensión que evolucione o se culmine hacia el final, y que no tendría el mismo efecto si la distribución de los elementos estudiados tuviera lugar en sentido inverso.

Una vez apuntado este procedimiento en el caso de la escritura del poema en prosa en Vallejo, habría que determinar, en un estudio que excede los límites de este trabajo, si éste responde únicamente a las circunstancias históricas y 
personales particulares de la creación de estos poemas, o si podría hacerse extensivo al resto de poemas en prosa de este autor, e incluso, si podría generalizarse a la escritura de este tipo de textos en otros autores. En caso afirmativo, este procedimiento podría proponerse como un rasgo propio de la escritura del poema en prosa, lo que contribuiría, en la línea de las necesidades o carencias señaladas por la crítica para este tipo de escritura mencionadas al inicio, a defender su caracterización y consolidación como un género literario distinto y particular.

\section{Referencias bibliográficas}

Arévalo, Guillermo Alberto. César Vallejo. Poesía en la historia. Colombia: Carlos Valencia Editores, 1977.

Aullón de Haro, Pedro, "Ensayo sobre la aparición y desarrollo del Poema en Prosa en la literatura española", Analecta Malacitana, vol. 2, nº 1 (1979), pp. 109-136.

Bernard, Suzanne. Le poème en prose de Baudelaire jusqu'a nos tours. Paris: Librairie Nizet, 1959.

Borgeson, Paul, "Los versos prosados de César Vallejo", en Fernando Burgos ed. Prosa hispánica de vanguardia. Madrid: Orígenes, 1986, pp. 137-145.

Bousoño, Carlos. Teoría de la expresión poética. Madrid: Gredos, 1985.

Chapelan, Maurice,(ed.). Anthologie du poème en prose. Paris: Julliard, 1946.

Coddou, Marcelo, "El recuerdo en la poesía de César Vallejo", Cuadernos Hispanoamericanos, $\mathrm{n}^{\circ} .295$ (1975), pp. 102-123.

Dávila, Elisa. El poema en prosa en Hispanoamérica: A propósito de Luis Cardoza y Aragón. Santa Bárbara: University of California Press, 1983.

Díaz Plaja, Guillermo. El poema en prosa en España. Estudio crítico y antología. Barcelona: Gustavo Gili, 1956.

Domínguez Caparrós, José. Métrica española. Madrid: Síntesis, 2000.

González Montes, Antonio. Escalas hacia la modernización narrativa. Análisis de la obra publicada por César Vallejo. Lima: Fondo de UNMSM, 2002.

Ferrari, Américo. El universo poético de César Vallejo. Caracas: Monte Ávila, 1972.

Iibérico, Mariano, 1965 "El sentido del tiempo en la poesía de César Vallejo", Revista Peruana de Cultura, $\mathrm{n}^{\circ} .4$ (1965), pp. 47-63.

León Felipe, Benigno (ed.). Antología del poema en prosa en español. Madrid: Biblioteca Nueva, 2005.

Martínez García, Francisco. César Vallejo. Acercamiento al hombre y al poeta. México: Colegio Universitario de León, 1976.

- "Referencias bíblico-religiosas en la poesía de César Vallejo y su función desde una perspectiva crítica", Cuadernos Hispanoamericanos, $\mathrm{n}^{\circ} .456-457$ (1988), pp. 641-715.

Meo Zilio, Giovanni. Estilo y poesía en César Vallejo. Perú: Editorial Universitaria/Horizonte, 2002.

Paz, Octavio. El arco y la lira. México: FCE, 1972.

Riffaterre, Michael, "La sémiotique d'un genre: le poème en prose", en Sémiotique de la poésie. Paris: Editions du Seuil, 1983.

Schneider, Emily. The poetry of César Vallejo and the interwar European avant-garde. Cambridge, Mass.: Harvard University Press, 1990.

Smith, Mark, "Los recursos retóricos en la poesía de Vallejo", Hispanófila, no 78 (1983), pp. 77-84.

Sucre, Guillermo. La máscara, la transparencia. Ensayos sobre poesía hispanoamericana. México: FCE, 1985. 
Utrera Torremocha, Ma . Victoria. Teoría del poema en prosa. Sevilla: Universidad de Sevilla, 1999.

Vallejo, César. Poemas en prosa. Poemas humanos. España, aparta de mí este cáliz. Ed. de Julio Vélez. Madrid: Cátedra, 1988.

Yurkievich, Saúl. Fundadores de la nueva poesía latinoamericana. Barcelona: Seix Barral, 1971. 